\title{
ROGER BACON ON THE ERRORS OF PHYSICIANS*
}

\author{
by \\ SIR JOHN GHARLES
}

'I AM a brother to Dragons', said Job, and Roger Bacon might on occasion have claimed a similar fraternal tie.

However much we may smile at the gullibility of Bacon and his mediaeval contemporaries in this matter of 'Dragons', we must remember that as late as I564, Conrad Gesner, the Swiss naturalist, permitted the 'Familia Draconum' to appear in his great work the Historia Animalium as part of the fauna known to science.

Dragons, whether sacred or secular, suave or savage, whether concerned with the guardianship of such sacred places as the temple at Delphi or the shrines of Aesculapius, whether acting as the beneficient watchdogs for humanity in the underworld, 'the sharp-eyed dwellers in the inner parts of the earth', wise to discover its secrets and enunciate them oracularly, or on the other hand as the frightful, ravaging, fire-breathing enemies of mankind-they were all part of the mediaeval consciousness. It is, therefore, not altogether surprising that we should find Roger Bacon descanting upon them in his 'Opus Majus'. Here is what he says:

Aristotle, moreover, in the book of Secrets recommends strongly the flesh of the Tyrian snake for our ills. The snake that is the food of the Aethiopians is the dragon, as David says in the Psalms, 'Thou hast given it as food to the tribes of the Aethiopians'. For it is certain that wise men of Aethiopia have come to Italy, Spain, France, England, and those lands of the Christians in which there are good flying dragons, and by the secret art they possess lure the dragons from their caverns. They have saddles and bridles in readiness, and they ride on these dragons and drive them in the air at high speed, so that the rigidity of their flesh may be overcome and its hardness tempered, just as in the case of boars and bears and bulls that are driven about by dogs and beaten in various ways before they are killed for food. After they have domesticated the dragons in this way they have the art of preparing their flesh, similar to the art of preparing the flesh of the Tyrian snake, and they use the flesh against the accidents of old age. The dragon's flesh prolongs their lives and sharpens their intellects beyond all conception. For no instruction that can be given by man can produce such wisdom as the eating of this flesh, and this we have learned through men of proved reliability on whose word no doubt can be cast.

Nor is this acceptance of marvels unique for one finds it again and again in other Baconian treatises, and in particular and in the most revealing way in his commentary on that strange and recondite work already mentioned, the Secreta Secretorum of Aristotle, one of whose alternative titles is The Book of the Ten Sciences.

It is clear from both internal and external evidence that the Secreta Secretorum

* Gideon de Laune Lecture delivered before the Faculty of the History of Medicine and Pharmacy of the Society of Apothecaries on 20 June 1960. 


\section{Sir John Charles}

has even less claim to be regarded as veritably 'Aristotelian', than the notorious thirty-eight Books of 'Problems', which to this day can provide any series of 'Quiz' sessions with an abundance of irrefragable material. But for Roger Bacon this curious, possibly Syriac rather than Greek compilation was the distilled wisdom of Aristotle, not the Aristotle of the Lyceum, communing freely with all who came about him, but Aristotle, the esoteric philosopher, the purveyor of secret doctrines. The Secreta Secretorum, purported to be a book of advice reverentially submitted by Aristotle to his one-time pupil and later, master, 'Alexander the Great'. For Bacon it became a more fruitful source of quotation than any other of the great Aristotelian works-the Metaphysics, the Ethics or the Posterior Analytics. For our immediate purpose, it is also of importance, because the antithesis between Bacon's acceptance of its wonders, and the stark, austere clarity of his thinking on experimental science in general is so striking, that we must seek to understand and appreciate his ambivalence, before we come to consider the medical treatises.

Bacon's introduction to the annotated text of the Secreta Secretorum which he offers for study, is the quintessence of all the magic, mystery, shrewdness and human yearnings which the work itself sets out in full and repetitive detail. The mise en scine is set when Bacon defends Astrology as a profitable method of anticipating the future. The art consists in foreseeing possibilities which nevertheless can be modified by the exercise of free-will, or by divine intervention. The human body is changing every hour with the action of the various constellations and is thus disposed to certain actions, though not forced to undertake them. Kings and other rulers should take note of the effect on the soul, of this influence of the stars upon the body. If a true astrologer knew the precise birth date of a prince he could judge of his nature and qualities, and the possible outcome of their uncontrolled development. A choleric king, naturally inclined to pride and anger will be the disturber of neighbouring kingdoms, and the provoker of wars. But if such a king has good physicians learned in astrology, his evil complexion may be changed for the better.

Even to the false astrologers Aristotle would not deny the power to do much good. According as God wills they may be helpful in seeking out stolen goods by seeing their hiding places mirrored on such polished surfaces as the redpainted nails of young and innocent boys, shining basins or swords or the well-rubbed scapula of a ram.

Many other subjects are touched on in the pages of the Secreta Secretorum, which when considered in isolation, appear to have no relevance to physicians, the practice of medicine, or the preservation of health. Yet they appear again in the several treatises 'On the errors of physicians', 'The retardation of old age', and 'The regimen of life for the middle-aged and elderly'. However inconsequential these observations may appear at this moment, they are all components of the Baconian philosophy of medicine, and worthy of our immediate attention. Let us commence with the science of Physiognomy. This is the subject of a short chapter, allegedly by Aristotle, but supported by a Baconian commentary, for Bacon regards it as a science of great beauty and 


\section{Roger Bacon on the Errors of Physicians}

wisdom. It is useful in warning one against evil men, and helpful in obtaining the friendship of the good. All the features of the face, bodily form, gait and carriage are reviewed in order. Eyes for example are classified as great, medium sized, goggle, asses, shifty, and red. Special peculiarities are also noted. To their respective possessors are assigned appropriate characteristics. Altogether unreliable is the unfortunate individual who has twin pupils in a single eye.

Bacon, like Hippocrates, had some doubts of the validity of judgments made from physiognomy alone. The science made it possible to suspect the existence of a certain tendency, but did not establish its presence. Yet the wise man ought to express a reasonable doubt when he found violent and obvious signs. There was, however, one proviso. It was difficult to make physiognomical judgments on Christians. Divine grace could prevail over evil dispositions however large they might be writ on the countenance of the individual.

From a study of physiognomy, it is an easy transition to the making of comparisons between the characters of men and animals.

God in his glory did not create any creature wiser than man, nor did he gather together in any animal all the human qualities. But there is no human characteristic that cannot be found in some one animal or another. So that it may be said of man that he is bold as a lion, timid as a hare, greedy as a wolf, irritable as a dog, tough and spiteful as the lionness, domesticated as the dove, sly and crafty as the fox, simple and gentle as the lamb, swift and agile as the young kid, slow and sluggish as the bear, precious as the elephant, cheap as the donkey-indomitable as the bull, mute as the fish, luxuriant as the pig, useful as the horse-reasonable as an angel.

There is no animal, vegetable, element or mineral, sky or planet-which possesses any special quality which cannot be found in man. Hence his name, the lesser world, the microcosm.

And so to the actual preservation of health. One piece of advice said to have been given by Aristotle to Alexander, and approved by Bacon was to the effect that he should not trust himself to one physician, but if it were at all possible to have ten physicians, speaking with one voice. Yet as it was eminently advisable that no physician should know all the illnesses of a king, the Secreta Secretorum would enable him to cure himself in all ordinary circumstances. In order that health should be maintained a certain regimen must be pursued, excesses must be avoided and moderation should be the watchword. Yet it was useful to have some simple daily medicament which a man might benefit by, and not need anything more potent except in emergency. A certain king, it is recorded, accordingly gathered together his better physicians-an Indian, a Mede, and a Greek and enjoined them to produce such a medicine. Very sensibly the Greek suggested two full mouthfuls of warm water each morning. The Mede thought that on an empty stomach it would be beneficient to take some millet seed. The Indian said that if anyone took a small dose of cumin daily he would need no other medicine.

'Quot medici, tot medicamenta.' There were some things also which strengthened the body and added to the pleasure of living. Such were-light foods taken at the proper time, ease of the mind, jocund society, warm baths, soft beds, pleasant odours, delight in musical instruments, the hearing of 


\section{Sir Fohn Charles}

pleasant canticles, the wearing of beautiful and shining garments, the presence of chosen friends and discussion with them of the past and the future. Nor should the use of suitable ointments or the occasional emetic be omitted from the pleasures of life. Such a recital of sensuous delights recalls the evocation of comparable pleasures by a modern poet:

the strong crust of friendly bread and many tasting food,-the cool kindliness of sheets that smooth away trouble, - the benison of hot water.

At the heart of the Secreta Secretorum is the prescription for the universal, polyvalent medicine which is called 'The Inestimable Glory', or 'The Treasure of the Philosophers'. It was to be compounded of eight different medicines designed for the several viscera and for various therapeutic purposes-with honey as the general vehicle. It was a remedy of infinite virtue, dispersing all ills, expelling all pernicious humours, retarding age and generating joy. Bacon's comments upon it are to the effect that:

it gives the full natural life, that it has cured to his knowledge the greatest man in France both physically and morally, that it can be prepared by any physician who is rich enough, and moreover if the ingredients cannot be bought in England, they can be found in the large French Market-places, or at any rate in Montpellier.

These are some of the medical observations, and they constitute but a fraction of the Secreta Secretorum. It concerns itself principally with more recondite matters relating to the art of government, the selection of ministers and ambassadors, the prerogatives and ranks of the King's scribes, the government of generals, the management of war, how to be safe from its results, the secrets of astrology, and the magical sciences. Even in the conduct of war, it was important to yoke military tactics and magical devices together. It was indispensable to know the name of the opposing general for from this could be calculated by numerical processes the prospects of victory or defeat.

From this mixture of magic, myth, and old wives' tales all credulously accepted, one steps into another world in the first pages of Bacon's Opus Majus. Here one is challenged by an austere mind detached, almost disembodied, in its appraisal of human frailties and follies. And yet it is not devoid of sympathetic understanding, even though its approach to human problems is both sardonic and incisive. These are the words in which Bacon introduces his 'Offendicula'- the causes of error, which stand between man and his comprehension of the eternal verities.

Now there are four chief obstacles in grasping truth, which are stumbling blocks for every man, however learned, and scarcely allow anyone to win a clear title to learning -and they are:

submission to faulty and unworthy authority

influence of custom,

popular prejudice and

an ostentatious display of our own knowledge,

coupled with the concealment of our own ignorance.

Everyone is entangled in these difficulties, every rank is beset. From these deadly banes come all the evils of the human race; for the most useful, the greatest, the most beautiful lessons of knowledge as well as the secrets of all science and art, are as yet unknown. But, still 


\section{Roger Bacon on the Errors of Physicians}

worse, men blinded in the fog of these four errors do not perceive their own ignorance, but with every precaution cloak and defend it so as not to find a remedy, and worst of all, although they are in the densest shadows of error, they think they are in the full light of truth.

Henry Morley, six hundred years later, has remarked on the persistence of these grounds of human ignorance.

We still make sheep walks of second, third, fourth and fifth-hand references to authority, still we are the slaves of habit, still we are found following too frequently the untaught crowd; still we flinch from the righteous and wholesome phrase 'I do not know'.

Another equally revealing insight into Bacon's mind is to be found in his various discussions on experimental science. There are in his opinion two modes of acquiring knowledge, namely by reasoning and by experience. Reasoning draws a conclusion, but does not make the conclusion certain, nor does it remove doubt. That is only achieved when the mind arrives at a conclusion by the path of experience. So it follows that

a man who has never seen fire might prove by adequate reasoning that fire burns and injures and destroys things, yet his mind would not be satisfied until he has placed his hand or some combustible material in the fire, and he would then have proved by experience what reasoning had taught.

And again in mathematics the most convincing proof of the characteristics of the equilateral triangle-however they might have been arrived at by reasoning -is by measurement. Experimental science is, therefore, he concludes, a science in itself, and a method applicable to all sciences. It arrives at certitude only by direct verification; and by its methods gives certitude also to the other sciences. 'It is the queen of all sciences, and the end of all speculation.'

Only Roger Bacon could contain the hunting of flying dragons, the stumbling blocks to knowledge, and the certitude of experimental science within the compass of one human intellect. What does history tell us of the man? There is still much that is uncertain and at best conjectural. We are ignorant of the dates of his birth and of his death. We are not completely certain as to his birthplace. We do not know when, where or why he entered the order of the Franciscans. We do not know all the countries in which he resided; we are at a loss to know whether more of his life was passed in France than in England. or in Paris rather than at Oxford. We do not know why he was persecuted or imprisoned. Nevertheless, from all the available material it is possible to suggest the outlines of a biography.

Although the place of his birth cannot be stated with absolute certainty, probably the old Roman settlement of Ilchester, now a small Somerset town, had that honour. The date can be credibly fixed as within the first five years of the second decade of the thirteenth century. His family were wealthy and until they came on hard times in the middle of the century as a consequence of their adherence to Henry III, were always ready to provide Roger with the necessary funds for his experiments and travels. As was customary in those days he went to Oxford in his early teens, and the first record of his name in history is to be found in the story Mathew Paris relates in his Chronicles. The tale is a slender 


\section{Sir John Charles}

one but it shows how Bacon in 1233, at the age of twenty-one or twenty-two was bold enough to return a pert and punning answer to his king, Henry III, in the presence of a convocation of counts, barons and presumably learned clerks at Oxford.

During his early years at Oxford he came under the influence of that great Englishman and Suffolk peasant, Robert Grosseteste, later Bishop of Lincoln, but at that time engaged in stimulating all the departments of knowledge, as classified in his Compendium Scientiarum. From Grosseteste Bacon undoubtedly acquired his interest in mathematics. physics, philology and Greek, and absorbed a theology less pedantic than that of the schoolmen. We can surmise that this the first Oxford phase of Bacon's life lasted fifteen years, perhaps even twenty. It was probably of this particular period that he was able to say:

I sought the friendship of all wise men among the nations, and I caused young men to be trained in languages, in geometrical figures, in numbers, in the construction of tables, in the use of instruments-and in many other necessary things. During this time I spent more than 2000 pounds on these things and in the purchase of books and instruments.

But in 1240, the flower of all mediaeval universities, Paris, attracted him. To quote Dr. J. H. Bridges, the erudite editor of Bacon's Opus Majus:

From the middle of the twelfth to the close of the thirteenth century, Paris was the principal focus of intellectual life in Europe. Then as now it was the most international of cities; then as now it was the region in which thought was most swiftly transmitted into deed.

It is probable that within a year or two of arriving in Paris, Bacon joined the Franciscans, and came within the discipline of the Order. He also achieved a doctorate in Theology, and began to acquire a reputation as a teacher and as a controversialist. His interests, however, were still concentrated on mathematical and physical subjects, and it was his good fortune to find another man who provided just as great a stimulus to his development as had been given earlier by Grosseteste. This man, Peter of Maricourt, seems to have been a most selfeffacing personality, endowed with a scientific intellect of the highest order, and his influence upon Bacon was undoubtedly great.

After ten years in Paris Bacon returned to Oxford in or about the year I25I. His activities there seem to have been scientific rather than scholastic. It is to this period we can probably attribute his experiments on the making of gunpowder, his interests in mirrors and lenses, and his attempts to make both the simple microscope and the reflecting telescope. Looked at dispassionately the claims that have been made on his behalf as a great inventor are difficult to substantiate. Experiments there undoubtedly were, and much money was spent on instruments and machines. There is for example a record of his paying sixty pounds for a mirror in Paris. Yet it is clear that many of his most audacious ideas never reached the test of experiment. But as Emile Charles, his French biographer says of him:

What does it matter if he did not really discover the telescope before Galileo, or the steamengine before Watt, he had at any rate discovered something more important than these-an 


\section{Roger Bacon on the Errors of Physicians}

instrument which was both more valuable in itself and for its potentialities-the instrument of his scientific method.

Apart from his devotion to experiments, and to audacious speculation during this second Oxford phase, Bacon was also prone to hint, and even proclaim that the fourth Offendiculum - the presumption of knowledge-applied to many of his contemporaries and clerical superiors. His orthodoxy may not have been suspect, but his intellect and his growing influence made him the object of envy if not of hostility.

As a religious man he was amenable to discipline, and this ultimately took the form in 1257 of his return from Oxford to the supervision of the Paris house of his Order. There, however, he was not placed under any serious restrictions and was able to continue his educational activities in instructing young men in elementary mathematics and physics, and in the use of such few scientific instruments as were at hand. Upon Bacon, diligently performing the duties of this dreary, frustrating though worthy round, there suddenly descended in 1265 the order of the Sovereign Pontiff, Pope Clement IV. That order, incorporated in a letter addressed 'To our Dear son, Brother Roger, also named Bacon,' still exists, in copy, in the archives of the Vatican. It commanded him

in the name of Our Apostolic Authority, all contrary injunction of any prelate whatsoever notwithstanding, to send as quickly as possible, a clean copy of the works upon which you have been engaged, and the remedies you would suggest for the evils which you hold to be so dangerous.

Bacon thereupon embarked upon the writing of his Opus Majus. He encountered every form of obstacle: inaccessibility of books, lack of copyists, dearth of money, and the open disapproval of the heads of his Order. Yet within eighteen months, he had despatched to Rome the magistral Opus Majus - a work of some 250,000 words. It is a review of contemporary knowledge, and a guide whereby that knowledge can be used to enhance the nobility of life, to further the intercourse of man with man, and for the greater glory of God.

A few months later two other works, the Opus Minus and the Opus Tertium were also sent to Rome. The Opus Minus is by way of a glossary on the Opus Majus. The Opus Tertium is a brilliant summary of the whole trilogy, the more fascinating because it includes many details of Bacon's life.

All this happened before the end of 1267 , but Clement IV died in 1268, and it is doubtful whether he was ever able to consider these great documentary contributions to science and philosophy. Bacon appears to have returned to Oxford in 1268, and to have continued his previous mode of existence there, teaching, writing and experimenting.

But he was more than ever at odds with his superiors, and by now he was tilting deliberately at the corruption of the Church. Much that he wrote cannot have endeared him to his clerical contemporaries for he did not hesitate to proclaim that the false assumption of knowledge and concealment of ignorance 


\section{Sir Fohn Charles}

were often associated with an indulgence in the deadly sins, of pride, envy, anger, sloth, lust and gluttony.

It is not surprising, therefore, that he was summoned again to Paris, and judged by the superiors of the Franciscan Order. The record reads:

Many of the brothers condemned and denounced the doctrine of Roger Bacon the Englishman, Master of Theology, concerning certain suspicious novelties, for which the said Roger Bacon was condemned to prison, with order given to all the brethren that none should hold his doctrine but avoid it as reprobated by the Order.

His imprisonment lasted for fourteen years, from 1278 to 1292 , from his sixty-fourth year to his seventy-eighth.

The certain suspected novelties of which Bacon was accused have never been precisely identified. It is clear that they were not amongst the most serious of the 200 philosophic propositions condemned by the Archbishop of Paris in 1277 , for these included opinions altogether subversive of faith and morals. Nor did Bacon, even at his most forthright ever describe the Holy See-to quote the words of a fellow Franciscan who was condemned at the same time -as 'courtesan, fleshly, and the synagogue of the Devil'. Most probably his ardent interests in astronomy and astrology were magnified into a somewhat sinister indulgence in the black art of magic, and his insistence upon an experimental approach to science was regarded as an ill-advised attempt to enlarge the frontiers of knowledge beyond what was expedient. But his great fault had been to expose the ignorance and pretensions to wisdom of his superiors. For them the accusation of the fourth Offendiculum was an offence.

His imprisonment was no doubt grievous only in the sense that he was excluded from the enjoyment of his old interests, and obviously a restriction was placed on his writing, for during these fourteen years nothing came from that industrious pen. The harsh sentence of 1278 was due to the tyrannical temper of the Head of the Franciscan Order, Jerome d'Ascoli, and was not mitigated when, ten years later, he became Pope Nicholas IV. Relief only came when Nicholas IV died in 1292, and a more enlightened head of the Franciscan Order, Raymond Guafredi, allowed Bacon to go in peace. The old man returned to Oxford, and there began, at the age of seventy-eight, the composition of his last work, the 'Compendium of Theology'. Mellower, tinged even with dignified melancholy, for he did not mention his misfortunes, it was never finished. He died on some date unknown between 1292 and 1294. His place of burial is equally uncertain, but Oxford holds his bones and his dust, as it had held his humble Franciscan loyalty.

Bacon's fame rests on his great Trilogy, the Opera majus, minus and tertium, but there is a considerable corpus of other works, some trivial, others of greater substance, the whole representing an industry almost Galen like in its intensity and variety. How and why did he become interested in medicine? There would appear to be at least three reasons. To begin with, as can be seen in the Regimen Sanitatis Salerni, the Middle Ages displayed a somewhat curious ambivalence in their outlook on life. For some men indeed the prospect of the hereafter

$$
276
$$




\section{Roger Bacon on the Errors of Physicians}

provided them with every consolation; others showed an almost passionate interest in the maintenance of health and retardation of old age. Bacon, however he might feel as a monk, was cognisant of that interest as a man. Secondly, he loved his mystifications, and those purveyors of vigour and vitality, the seven occult remedies gave him ample opportunity for esoteric allusions. The royal metal, the remedy 'thrown up by the sea', the medicine 'provided by the noble animal' and above all the 'squared stone' which is human blood, were certainly symbolic and possibly possessed of therapeutic virtue. And finally, it is perhaps not too much to suggest that in the preparation of the more mundane remedies, laxatives, oils, minerals and ordinary herbs, he was able to practise and to teach the use of simple physical, chemical processes which were inherent in the operations of experimental science. And in his attempts to fix standards for the measurement of heat, as required in the preparation of his medicaments, he was again enlarging its territory.

There are at least eight Baconian treatises of varying length and importance which have some sort of association with medicine. Four of them are concerned with the related questions of the preservation of youth, the retardation of old age and the prolongation of life. Three may be described as pharmaceutical, and the eighth is the racy, and despite its title, the helpfully critical Book on the mistakes of Physicians. All eight are written in a simple, easily flowing Latin, and their author has a gift for colourful phrasing-'Mundo senescente senescunt homines' he writes-Ageing men in an ageing world. 'Non est sanitas nisi humor purgetur'-There is no health unless the humor can be purified, and then the opening challenge of the De Erroribus, 'Vulgus medicorum non cognoscit'-The crowd of physicians is ignorant, from which gambit he proceeds to discuss their deficiencies.

The treatise on the preservation of youth, and the epistle on the retardation of the accidents of old age, are in a sense mirror images. The requirements for the maintenance of youth, are, of course, the preventive medicine against old age. However, no doubt because youth is heedless and inattentive, and old age has time and money on its hands, and its latter end in more immediate contemplation, the Epistle on retardation is at least three times as long as the treatise on youth's conservation. Bacon has his own definition of the starting point of old age and of its several stages. He does not accept the common assumption that old age, or to use a more euphemistic description the period of 'declination' has its commencement at the age of sixty. He prefers to regard it as beginning when the prime of life is over, say at forty-five or fifty. Like Hippocrates and Shakespeare he sees stages in the march of old age, and recognizes three groups of wayfarers, Senes, the old; Seniores, the elders; andthe decrepit. The signs and symptoms of old age (and his catalogue of these is very extensive) are due to a drying up of the natural juices, with which is unhappily combined, an invasion of excessive extraneous humors, as exemplified by his special morbific bug-bear, the phlegm. Seeking for the real causes of this gradual failure of vital powers, he blames the air we breathe, excesses of food and drink, lack of sleep, restlessness of the body, and agitation of mind. The 


\section{Sir Fohn Charles}

Bacon of the experimental method, hints in a remarkable and percipient passage that the prevention of old age will be effective when it is possible to measure the respective influences of these six causes. He poses a series of questions. Who will escape the air infected with poisonous vapours? Who will make measurements of food and drink, of sleep and wakefulness of movement, and quiet, and of all those things that flow away or are retained, and of all that happens in the mind, and whether they are on one side of the mark or the other? And he answers rhetorically 'No one at all.' And so the question of how to retard the onset of old age is simplified, and dealt with under two heads, by following a proper regimen of life, and by the constant use of the occult remedies. These, alas, are only for the rich and powerful, for they are subject to three disadvantages, cost, great potency, and vulgar fame. And yet until nature herself masters the science of measurement, they are the best suited to regulate and adjust all the factors that matter, age, constitution and season, in conserving bodily health.

Little need be said of the three pharmaceutical treatises, for their substance is to be found in great part in the De Erroribus Medicorum itself.

None of the Baconian medical treatises can approach the De Erroribus in originality of thought or pertinence of expression. It consists of an essay of some 6,00o words, followed by some notes on drugs and remedies. From its opening sentence about the ignorance of physicians to its culminating statement, so singular in an age of faith that neither authority nor argument are as effective as experiment in bringing quiet to the mind, it moves on without repetition swiftly and coherently in vivid and memorable phrases. As to when it was written we have no certain knowledge, but it reflects much of the thinking of the Opus Majus and it was possibly one of the fruits of that halcyon period in Oxford between 1268 and 1278.

The late Dr. Withington, whose lively commentaries on Bacon have placed all later students in his debt, has stressed two 'prominent peculiarities' about the medical treatises in general and the De Erroribus in particular.

They are [he says] the production of a man of singularly practical mind who was not in practice and had ... few opportunities of getting certitude by experience [and secondly], the writer, though by nature a rebel against authority ... nevertheless accepts without question a theory of medicine, eminently based upon authority, the system of Galen, as further formularized and stereotyped by Avicenna and the 'Arabs'.

There is little in the De Erroribus which one can regard even remotely as clinical. There are none of those bedside vignettes we find in the ancient writers, brief and sharply drawn in the case of Hippocrates, copious and discursive when Galen is in charge of the patient. One has the impression of an extremely learned would-be experimenter and practitioner, anxious to try out his pharmacopeia on family, friends or farmyard, but restricted by circumstances to the uncertain pleasure of self-medication and to prescribing his 'Occulta' against the premature onset of old age.

Bacon's erudition was indeed outstanding, but here again, although 278 


\section{Roger Bacon on the Errors of Physicians}

conversant with Latin, Greek and Hebrew and to a considerable extent with Arabic, he was obliged to take most of his 'ancient medicine' not from the original sources but at second-hand, from the great Arab physicians and the medical texts they published. The descent of the basic doctrines might be almost direct, and their content unaltered and unimpaired, but the Moslem physicians, from their own vast experience and by reason of their particular outlook on life, could not fail to give some eastern colour and emphasis to the ideas of Hippocrates and Galen. Bacon in the matter of medicine was Avicenna's man rather than a disciple of the Greek masters. Yet in one fundamental matter, the acceptance of 'The Doctrine of Humors', his devotion to the Arab doctors, rather than to the Greek, made no difference at all.

'The Doctrine of the four Humors' with its implicit association with the Empedoclean elements, the four physical qualities, human characters and dispositions and a host of other attributes, seasonal, climatic, even pharmaceutical, provided a coherent system of medicine good for two thousand years. It was sufficiently rationalized to resist the experimental yearnings of Roger Bacon.

It would be a mistake to conclude that the De Erroribus is merely an indictment of physicians or a diatribe against them. Its purpose is more profound than that, for in essence it is a constructive criticism of what we would now call 'Medical Education' and beyond that of the failings of mediaeval education in general, as made manifest by the ignorance of the common herd of students of philosophy.

Bacon uses the word 'medicina' in two senses, to denote the art and science of physic, and on the other hand as describing all that is contained in pharmacy, the knowledge of drugs, their preparation and uses. It is in the latter sense that 'medicina' appears in the flamboyant opening sentence of the De Erroribus to which I have already referred. 'Vulgus medicorum non cognoscit suam simplicem medicinam', he proclaims, and then proceeds to say that the doctors are in the hands of the apothecaries and have surrendered to the deceptions, substitutions and frauds of the latter-all of which lies heavily not so much upon the physicians as upon their patients. (Lest any member of the Worshipful Company of the Apothecaries should take this as an unfriendly aspersion on apothecaries in general and inappropriate on this commemorative occasion, let me remind him that an interval of more than 300 years separated Roger Bacon from Gideon de Laune, and the same period of time lies between that great Master of the Society and ourselves.)

Then with another blast of rhetoric like 'the great text in Galatians' which 'entails twenty-nine distinct damnations', Bacon embarks upon the thirty-six defects which afflict the pharmacy of his time. And when he has analysed a mystical seven of these faults, each of them a variation on the theme that drugs are not what they seem, or are alleged to be, with similar rhetorical gusto he closes down on the remaining twenty-eight, saying in effect ' $I$ can't be bothered with them. I have more important matters to comment upon'. So he passes over to the discussion of the so-called 'extrinsic' impediments which 


\section{Sir John Charles}

confront the students of medicine. By and large these amount to six salient types of ignorance, or neglect of existing knowledge. Certain of them are as relevant to our present situation as they were to the needs of the physicians of the thirteenth century. The first is ignorance of the languages from which a knowledge of medicine can be acquired. The original source books are written in Arabic,' Greek, Chaldean and Hebrew, and many words find their way into the Latin texts, with the result that they are not understood, and ignorance is therein fostered. The second concerns the physician's ignorance of the drugs he uses. He cannot recognize them, he accepts old preparations when he should be receiving newly compounded ones, he is put off with substitute or sophisticated remedies, and above all he does not know what they cost. And the third fault is that the whole body of doctors has been so given over to disputations on ill-defined topics, and to futile argument, that it has not had time to benefit from experience. Dialectical arguments and trivial sophistries will not lead them to the truth. For in the practical sciences of which medicine is one, the faculty of invention operates through the use of the senses, through memory and experience. The fourth defect need not detain us unduly for it is the neglect of astrology, which Bacon commends as being worthy of consideration. Without its use the physician, he suggests, is much more dependent on chance and good fortune.

But the fifth field of ignorance and neglect moves Bacon to one of his most powerful submissions. It is that alchemy, by which he means the infant science of chemistry, has been too greatly neglected by students. With alchemy he couples agriculture, in which term are comprehended both botany and zoology. Chemistry, he is certain, will one day disclose the stuff out of which man and the universe are made. It can already be used to separate out the several humors from blood, and in the future may even show how the humors carry out their appointed tasks. Knowledge has hitherto advanced by proceeding from the universal to the particular by way of argument, and not by the way of certitude. Speculative alchemy moves from the study of the particular, to the universal, employing as its tool, experiment. From this it is almost an anticlimax to find that the final field of ignorance includes natural philosophy, and metaphysics, but there are other tenants of this field, not least amongst them the philosophers and the theologians.

Bacon having underlined these intellectual deficiencies of the physician, has not yet concluded. He would agree that in this matter of the speculative alchemy, medicine is in a difficult position, for the human body is precious stuff and cannot be submitted to the same experimental insults as inanimate material. Nevertheless, truth cannot be certified except by experiment, and on that account the physicians can be more readily excused than the other servants of science.

As he moves steadily on to his conclusions, Bacon asks himself why it is that races, like those of the north, using medicines sparsely and infrequently, produce men, strong and handsome, whose lives are longer than those of such other men as are dedicated addicts to their medicaments. He has also in mind 


\section{Roger Bacon on the Errors of Physicians}

perhaps those inhabitants of Britain whose bodies made dense by the climate, retain their innate heat for an immense period, and only grow old at 120 years -or at least Asclepiades says so.

From this point he reaches out to inquire what is lacking to the practice of medicine, and what are the gaps in medical knowledge.

He selects a number of these deficiencies, and as outstripping all others, he would place the lack of precision in diagnosing diseases, and in labelling them when identified. What is needed, he suggests, is a distinct recognition of diseases as entities, an attempt to classify them, and, if possible, some knowledge of their causation. Granted competent diagnosis, he would next point to the gross inadequacy of the armamentarium of drugs. There was still much to be learnt about remedies, both simple and compound. As proof of this statement he would invite attention to his own esteemed rhubarb, in all its eastern variety, which he had tried out on his own body. Moreover, Aristotle had recommended rhubarb to Alexander the Great, as giving life to the liver, and a warming comfort unlike that given by any other medicine. But, Bacon lamented, there are too many diseases for which we have no remedies.

Amongst other deficiencies he mentions again the prevailing ignorance of how the humors actually work. No one knew how their excesses or deficiencies were concerned in the causation of disease. In modern phraseology there was no information about the actual mechanisms of illness. For all this he offers his infallible prescription, the application of experimental science, and strides on to his final exposition on this subject. It is an exposition, more succinct, more lucid, and because of its brevity more cogent than anything he wrote at much greater length in the Opus Majus. He begins quietly. Admittedly truth may be reached through reasoning and argument. Yet doubt will still linger until truth has been made manifest by experience. And he produces again his favourite example of the fire and the finger which only finds certainty by experiment. He joins to this example the other familiar one of the equilateral triangle, whose sides are accepted as equal by the inquiring mind, only after measurement. He adds two new examples. One comes from The Posterior Analytics of Aristotle and is concerned to prove that the content of the angles of a triangle is equivalent to two right angles. And lastly the magnet-however much one might be persuaded by argument that iron is attracted to the magnet, nevertheless he will not be satisfied until his eyes have given him the proof.

Bacon, assured in his own mind that all these things are capable of verification, that they can by experiment acquire the virtue of certitude, sums it up in the pregnant final sentence-Neither the voice of authority, nor the weight of reason and argument are as significant as experiment, for thence comes quiet to the mind.

The De Erroribus Medicorum may belie the boisterous promise of its title, but medicine, pharmacy and science are the better for its purposeful illumination. 


\section{Sir John Charles}

\section{SOURCE MATERIAL}

TEXTS

1. Opus Majus of Roger Bacon. Edited by J. H. Bridges. 3 vols. Oxford, 1897-1900.

2. Opus Tertium of Roger Bacon. Edited by A. G. Little. Aberdeen, The University Press, 1912.

3. Opera hactenus inedita Rogeri Baconi. Fasc. V. (Secreta Secretorum, etc.). Edited R. Steele, with an English Translation from the Arabic by A. S. Fulton. Oxford, Clarendon Press, 1920.

4. Opera hactenus inedita Rogeri Baconi. Fasc. IX. (De Retardatione accidentium senectutis, De erroribus Medicorum etc.). Edited by A. G. Little and E. Withington, Oxford, Clarendon Press, 1928.

TRANBLATION

5. The Opus Majus of Roger Bacon, I and II. Translated by R. B. Burke. Philadelphia, University of Pennsylvania Press, 1928.

BIOGRAPHY

6. Dict. Nat. Biog., II. R. Adamson.

7. Roger Bacon. Sa vie, ses ouvrages, ses doctrines. E. Charles. Paris, Hachette, $186 \mathrm{r}$. OTHER SOURGES

8. Introductory Essays to I (J. H. Bridges): 3 (R. Steele), and 4 (E. Withington).

9. Essays and Addresses. J. H. Bridges. London, 1907.

10. Roger Bacon: Essays contributed by various writers on the occasion of the seventh centenary of his birth. Collected and edited by A. G. Little. Oxford, 1914.

11. English Writers, m. Henry Morley. London, Cassell, 1888. 